\title{
SENAM NIFAS BERSAMA DALAM PROSES INVOLUSI UTERI PADA IBU POST PARTUM DI BPS IDA SISWIASTUTIK KOTA PANGKALAN BUN
}

\author{
${ }^{1}$ Jenny Oktarina \\ ${ }^{1}$ STIKes Borneo Cendekia Medika \\ ${ }^{1}$ Email : oktarina.jenny@yahoo.co.id
}

\begin{abstract}
ABSTRAK
Masa nifas (peurperium) dimulai setelah kelahiran plasenta dan berakhir ketika alatalat kandungan kembali seperti keadaan sebelum hamil. Masa nifas berlangsung selama kirakira 6 minggu. Proses pemulihan kesehatan pada masa nifas merupakan hal yang sangat penting bagi ibu setelah melahirkan, dimana ligamen-ligamen dan diafragma pelvis serta fasia yang meregang sewaktu kehamilan dan persalinan, setelah janin lahir berangsur-angsur kembali seperti sedia kala. Tidak jarang ligamen menjadi kendor yang mengakibatkan uterus jatuh kebelakang, tidak jarang pula wanita mengeluh kandungannya turun setelah melahirkan oleh karena ligamen, fasia, jaringan penunjang alat genetalia menjadi agak kendor. Untuk memulihkan kembali jaringan jaringan penunjang alat genitalia tersebut, juga otot-otot dinding perut dan dasar panggul dianjurkan untuk melakukan latihan-latihan fisioterapi tertentu yang dapat dilakukan pada dua hari post partum.

Khalayak sasaran dari pengabdian masyarakat ini ialah ibu-ibu post partum yang melakukan kunjungan di BPS Ida Siswiastutik. Untuk memecahkan permasalahan yang dihadapi dalam kegiatan ini, maka dipilih beberapa metode pemecahan sebagai berikut: 1) Metode ceramah dan tanya jawab digunakan saat penyampaian materi senam nifas. 2) Metode demonstrasi dan latihan digunakan pada saat mempraktikkan senam nifas.

Kegiatan dilaksanakan di BPS Ida Siswiastutik karena ibu post partum di BPS tersebut belum mengetahui tentang senam nifas dan tidak mengetahui cara melakukan senam nifas. Waktu pelaksanaan kegiatan selama 90 menit yang meliputi apersepsi tentang senam nifas, penyampaian pendidikan kesehatan tentang senam nifas, tanya jawab, demonstrasi senam nifas, redemonstrasi senam nifas dan evaluasi pendidikan kesehatan yang telah disampaikan kepada responden post partum.
\end{abstract}

\section{Kata kunci : Tingkat Kecemasan, KIE, Menopause}

\begin{abstract}
The puerperium ( peurperium) started after birth the placenta and end when the tools back the way things were before pregnant.The puerperium lasts for about six weeks. The process of restoring health in winter season is a very important point for women after delivery, where ligamen-ligamen and the diaphragm the pelvis and fascia that stretched when pregnancy and childbirth, after a fetus born slip back to life again.It is not uncommon ligaments become lax resulting in the uterus fall back, are not woman complain their burden down after giving birth because of ligaments, fascia, supporting tissue genetalia instrument to become rather lax.To reconcile the external instrument supporting tissue network, also the muscles of the abdominal wall and the base of the pelvis advisable to do certain physiotherapy exercises may be conducted in two days post partum. By the people the target groups of this public devotion is mothers post partum who performs his visit here ida siswiastutik bps.To solve the problems faced by in this activity, selected some method of solving as follows: 1 ) the method of lectures and a question and answer session in use at the time for the delivery of material gymnastic who have just given birth .2) the method of demonstrations and put into practice all day gymnastic exercise in use at the time who have just given birth. Should be implemented
\end{abstract}


in bps ida siswiastutik because the mother post partum in bps has not yet been aware of gymnastic who have just given birth and do not know how to do gymnastics who have just given birth.The period for implementation of activity during 90 minutes which includes apersepsi about gymnastic who have just given birth, the delivery of health education about gymnastic who have just given birth, a question and answer session, a demonstration gymnastic who have just given birth, who have just given birth and evaluation gymnastic redemonstrasi health education which was delivered verbally to respondents post partum.

Password: the level of anxiety, kie, menopause

\section{Pendahuluan}

Masa nifas (peurperium) dimulai setelah kelahiran plasenta dan berakhir ketika alat-alat kandungan kembali seperti keadaan sebelum hamil. Masa nifas berlangsung selama kira-kira 6 minggu. Proses pemulihan kesehatan pada masa nifas merupakan hal yang sangat penting bagi ibu setelah melahirkan, dimana ligamen-ligamen dan diafragma pelvis serta fasia yang meregang sewaktu kehamilan dan persalinan, setelah janin lahir berangsur-angsur kembali seperti sedia kala. Tidak jarang ligamen menjadi kendor yang mengakibatkan uterus jatuh kebelakang, tidak jarang pula wanita mengeluh kandungannya turun setelah melahirkan oleh karena ligamen, fasia, jaringan penunjang alat genetalia menjadi agak kendor. Untuk memulihkan kembali jaringan jaringan penunjang alat genitalia tersebut, juga otot-otot dinding perut dan dasar panggul dianjurkan untuk melakukan latihan-latihan fisioterapi tertentu yang dapat dilakukan pada dua hari post partum.

Selama masa nifas ibu banyak mengalami perubahan fisik seperti dinding perut menjadi kendor, longgarnya liang senggama dan otot dasar panggul. Untuk mengembalikan kepada keadaan normal dan menjaga kesehatan tetap prima, senam nifas sangat baik dilakukan pada ibu setelah melahirkan.

Menurut data statistik yang di keluarkan World Health Organization (WHO) sebagai Badan Perserikatan Bangsa-Bangsa (PBB) yang menangani masalah bidang kesehatan, tercatat angka kematian ibu dalam kehamilan dan persalinan didunia mencapai 515.000 jiwa setiap tahun. AKI Indonesia masih tertinggi di Asia, di Indonesia tahun 2010 sebanyak 102 ibu meninggal setiap 100.000 kelahiran. Target MDGS sampai dengan Tahun 2015, ditargetkan AKI turun sampai 102/100.000 kelahiran hidup. AKI tahun 2010 di Jawa Timur 598/100.000 kelahiran hidup, angka kematian ibu nifas sebanyak 283/100.000 kelahiran hidup. Angka kematian ibu (AKI) di Kabupaten Mojokerto tahun 2012 adalah 116,89/100.000 kelahiran hidup, angka kematian ibu nifas sebanyak 36,91 /100.000 kelahiran hidup ,12,31/100.000 kelahiran hidup disebabkan perdarahan pada masa nifas, 24,60/100.000 kelahiran hidup disebabkan infeksi pada masa nifas.

Pada ibu post partum terjadi perubahan pada alat kandungan, otot-otot uterus banyak mengalami peregangan akibat kehamilan.Untuk membantu mengembalikan uterus ke bentuk dan kondisi semula, tak bisa lain harus dengan latihan senam nifas yang teratur. Apabila ibu bersalin melakukan senam nifas, bisa mengurangi rasa sakit pada otot, memperbaiki peredaran darah, mengencangkan otot-otot perut dan perineum, mempercepat involusi uterus, memperlancar lochea, dan mencegah komplikasi yang timbul pada waktu nifas. Dengan kontraksi uterus yang baik, diharapkan rahim bisa kembali mengerut ke ukuran normal tanpa bantuan obatobatan. Secara otomatis rahim akan berkontraksi dengan sendirinya, kontraksi ini ikut mengerutkan kembali saluran kemih yang mengendor akibat membesarnya rahim selama kehamilan. Hanya saja saluran tersebut maupun otot- 
otot tidak akan langsung mengerut secara otomatis melainkan harus dibantu pengencangannya kembali lewat senam khusus yaitu senam nifas. Senam nifas mempunyai beberapa manfaat antara lain dapat mempercepat penyembuhan , membuat jahitan lebih rapat, meredakan hemoroid, meningkatkan pengendalian atas urine, dan mengencangkan otot-otot abdomen setelah melahirkan.

$$
\text { Dampak apabila tidak }
$$

dilakukannya senam nifas kemungkinan akan mengakibatkan proses involusio yang berjalan lambat dan kemungkinan terjadinya trombo plebitis sehingga perlu adanya upaya pencegahan bahaya nifas adalah dengan senantiasa melakukan senam nifas sesudah persalinan.

\section{Metode}

Khalayak sasaran dari pengabdian masyarakat ini ialah ibu-ibu post partum yang melakukan kunjungan di BPS Ida Siswiastutik. Untuk memecahkan permasalahan yang dihadapi dalam kegiatan ini, maka dipilih beberapa metode pemecahan sebagai berikut:

1. Metode ceramah dan tanya jawab digunakan saat penyampaian materi senam nifas.

2. Metode demonstrasi dan latihan digunakan pada saat mempraktikkan senam nifas.

\section{Hasil dan Pembahasan}

Pendidikan kesehatan diberikan kepada ibu post partum di BPS Ida Siswiastutik Kota Pangkalan Bun. Pendidikan kesehatan tersebut diberikan kepada 6 responden ibu post partum dan pelaksanaan pendidikan kesehatan dihadiri 2 bidan. Ketika dilakukan apersepsi mengenai senam nifas, tidak ada yang mengetahui senam nifas dan belum pernah melakukan senam nifas. Responden sangat antusias mengikuti kegiatan dari awal sampai akhir. Ada beberapa pertanyaan yang ditanyakan responden mengenai materi yang belum dimengerti.

Kegiatan dilaksanakan di BPS Ida Siswiastutik karena ibu post partum di BPS tersebut belum mengetahui tentang senam nifas dan tidak mengetahui cara melakukan senam nifas. Waktu pelaksanaan kegiatan selama 90 menit yang meliputi apersepsi tentang senam nifas, penyampaian pendidikan kesehatan tentang senam nifas, tanya jawab, demonstrasi senam nifas, redemonstrasi senam nifas dan evaluasi pendidikan kesehatan yang telah disampaikan kepada responden post partum.

Setelah kegiatan pengabdian masyarakat terkait senam nifas, responden post partum mengetahui tentang pentingnya senam nifas dan dapat mendemonstrasikan senam nifas yang telah diajarkan.

\section{Kesimpulan dan Saran \\ Kesimpulan}

Senam nifas adalah latihan gerak yang dilakukan secepat mungkin setelah melahirkan, supaya otot-otot yang mengalami peregangan selama kehamilan dan persalinan dapat kembali kepada kondisi normal seperti semula.

Proses pemulihan kesehatan ibu pada masa nifas merupakan suatu hal yang sangat penting dan ikut menentukan berhasil tidaknya peran dan fungsi keluarga, dimana keluarga mendukung proses pemulihan ibu post partum. Pada masa nifas akan mengalami perubahan baik fisik maupun psikis. Perubahan fisik meliputi ligamen-ligamen bersifat lembut dan kendor otot-otot tegang, uterus membesar postur tubuh berubah sebagai kompensasi terhadap perubahan berat badan pada masa hamil.

\section{Saran}

Agar senam nifas dapat dilakukan supaya membantu:

1. Memperlancar terjadinya proses involusi uteri (kembalinya rahim ke bentuk semula). 
2. Mempercepat pemulihan kondisi tubuh ibu setelah melahirkan pada kondisi semula

3. Mencegah komplikasi yang mungkin timbul selama menjalani masa nifas

4. Memelihara dan memperkuat kekuatan otot perut, otot dasar panggul, serta otot pergerakan.

5. Memperbaiki sirkulasi darah, sikap tubuh setelah hamil dan melahirkan, tonus otot pelvis, regangan otot tungkai bawah.

6. Menghindari pembengkakan pada pergelangan kaki dan mencegah timbulnya varises.

\section{Daftar Pustaka}

Ambarwati, 2008. Asuhan Kebidanan Nifas. Yogyakarta: Mitra Cendikia. (hlm: 97-115).

Andrews, Gilly. (2009). Buku Ajar Kesehatan Reproduksi Wanita (Women's Sexual Health). Addison Wesley Longman China Limited. Hong Kong GCC/02. Alih Bahasa, Sari Kurnianingsih. Jakarta: EGC

Baecke J.A.H, Burema, J. and Frijters, J.E.R. (1982). A Short Questionnaire for the Measurement of Habitual Physical Activity in Epidemilogical Studies. American Journal of Clin Nurt. 36.

Saleha, 2009. Asuhan Kebidanan Pada Masa Nifas. Jakarta: Salemba Medika (hlm: 71-76).

Suherni, 2007. Perawatan Masa Nifas. Yogyakarta: Fitramaya. (hlm: 101118). 